\title{
The usage pattern and willingness of undergraduate medical students for including social media platforms as a learning tool in medical education- an online survey
}

\author{
Momin Sayed Kashif ${ }^{1}$, Mirza Nisar Hussain Baig ${ }^{2}$ \\ ${ }^{1}$ First author: Assistant Professor, Department of Community Medicine, PIMS, Karimnagar. \\ ${ }^{2}$ Corresponding author: Professor, Department of Physiology, PIMS, Karimnagar.
}

Address for correspondence: Department of SPM, Prathima institute of Medical Sciences, Nagnur Road, Karimnagar, Telangana 505001.

\section{ABSTRACT}

Background: The rapid growth and availability of smartphones and social media platforms (SMP) have changed the medical students' approach to learn and manage the information about their academic, personal and professional lives.

Methods: An online survey was done in undergraduate medical students of PIMS, Karimnagar to collect information about usage pattern and perception of SMP, and willingness to participate for using SMP as a learning tool in medical education.

Results: Total 433 (Females - 275) out of 600 students participated in the survey from the first year (125), secondyear (151) and third-year (157) MBBS students. Everyone is using some type of SMP. They find SMP nearly equal to lecture materials and subject notes as a useful learning tool and there was significantly increasing trend of perception of SMP being a useful learning tool from the first-year (79\%), second-year $(83 \%)$ to third-year (92\%), ( $p=0.01)$. Almost 93\% want to see SMP used at institute level in medical education. Female students (52.4\%) are significantly more willing for active participation than male students $(43 \%), p=0.04$. First-year students (56\%) are more ready for active participation followed by third (48.4\%) and second (43.7\%) year students, $p=0.08$.

Conclusion: Most students are willing to include SMP in medical education as a learning tool and ready to participate in different activities if they get the required training. As all students have smartphones and efficiently utilizing different services on their devices, SMP can become an effective learning tool in medical education.

Keywords: Social Media, Social Media Platform, Social Networking, Medical Education, Teaching and learning methods, Online learning.
Introduction :

Social media platforms (SMP) are nowadays more commonly used by students, faculties and by the rest of the population worldwide to communicate, collect information, and share information. ${ }^{(1)}$ The internet rather than the library is now the usual source of knowledge and to prepare qualified doctors for this new learning environment, the teaching methods used for educating and training medical students should be reconsidered. ${ }^{(2)}$ The rapid growth and availability of social networking websites have changed the medical students' approach to learn and manage the information about their academic, personal and professional lives. Social media platforms can be used to connect the medical students to each other, enhance learning from peers, share content, connect outside the classroom, easily exchange ideas, and connect with teachers. The teacher can provide guidance for self-directed learning, engage them in an academic discussion by providing relevant contexts like a case or problem-based materials. ${ }^{(3)}$

Many medical institutes have shifted toward a "flipped classroom" model for learning where students should learn and prepare independently before attending classroom lectures. ${ }^{(4)}$ Similarly the practice of blended learning which includes a combination of face-to-face traditional and online learning methodologies as part of the curriculum can provide teachers with a broad spectrum of tools to create and deliver effective quality education. ${ }^{(5)}$

The effectiveness of online learning particularly using SMP is influenced by many factors. Some factors create barriers such as administrative issues, technical problems, cost and access to the internet and some are personnel or social barriers such as learner motivation, time and support for studies, academic skills, technical skills, and social interaction, etc. ${ }^{(2)}$ 
The aim of this study is to understand the medical students' opinion on the using of social media platforms for learning and development of medical education and to assess their perception, willingness and how best SMP can be incorporated into medical education at institute level.

Methods: The study was conducted in June 2019 at Prathima Institute of Medical Sciences (PIMS), Nagunoor, district Karimnagar, Telangana among MBBS undergraduate students.

Pilot study: First the survey form was tested for its feasibility, questions' comprehension and ease of filling forms. Reliability analysis was carried out on the values scale comprising 10 items. Cronbach's alpha showed the questionnaire to reach acceptable reliability, $\propto=0.81$.

All $(n=600)$ first year to third-year (Part-1) medical students from PIMS, Karimnagar were contacted in their respective classrooms to participate in an anonymous online questionnaire hosted on Google forms

Online survey form: Students were asked to identify, on a fivepoint Likert scale, usefulness and their usage pattern of social media for social and educational purposes. They were also asked to state their perception and willingness of participation if one of social media platforms would be used at institute level in medical education.

Data collection: The students were contacted in their respective classrooms. The link to the online questionnaire was shared on the WhatsApp group of the respective batch in the classroom and the students filled the survey form online on their smartphones at that time only. Any login or network issues were resolved immediately. The survey could be submitted only once and those students who were absent at the time of the survey were excluded.

Statistical analysis: Survey scales employed 5-point Likert scale measures for self-reported usefulness of social media in medical education (Not useful $=1$, Not very useful = 2, Neutral = 3, Somewhat useful $=4$, Very useful $=5$ ) and for usage pattern (Never $=1$, Rarely = 2, Sometimes = 3, Often = 4, Always $=5$ ). Simple frequencies were calculated for respondent characteristics and responses to survey questions. The categories of $1 \& 2$, and $4 \& 5$, are clubbed for statistical analysis. Kruskal Wallis Test was employed to assess for the differences in preferences, willingness, and participation between male and female students and among first to thirdyear students.

Results:

Total 433 (Females - 275) out of 600 students participated in the survey from the first year (125), second-year (151) and third-year (157) MBBS students of Prathima Institute of Medical Sciences, Karimnagar (TS). The results based on gender-wise and year-wise comparisons are presented under the following headings.

Figure 1 . How useful do you find following different learning tools in your medical education?

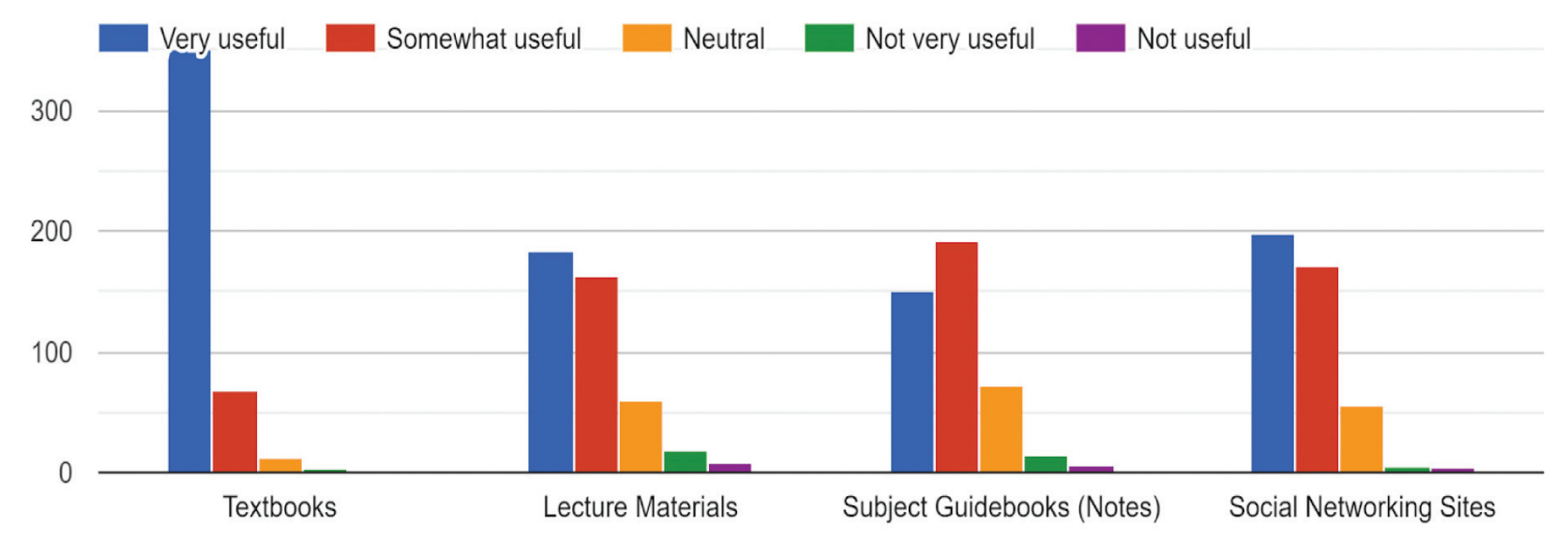

Useful Learning Tools: More than 95\% of students find the textbook as a useful learning tool. They also find SMP nearly equal to lecture materials and subject notes as a useful learning tool in their medical education (Figure 1). There is no significant difference between male and female students' perceptions of the usefulness of SMP and other learning tools. Almost $85 \%$

of first and second-year students consider lecture materials useful compared to only $69 \%$ of third-year students, $p<0.01$ and conversely there is significant increasing trend of SMP as a useful learning tool from the first-year (79\%), second-year $(83 \%)$ to third-year $(92 \%),(p=0.01)$. 
Table 1 Gender wise differences among medical students about SMP in medical education

\begin{tabular}{|c|c|c|c|c|}
\hline $\begin{array}{c}\text { Survey } \\
\text { Questions\$ }\end{array}$ & Options & $\begin{array}{l}\text { Female } \\
(n=275) \\
\text { No. }(\%)\end{array}$ & $\begin{array}{c}\text { Male } \\
(n=158) \\
\text { No. }(\%)\end{array}$ & $\begin{array}{c}\text { Significance } \\
\text { ( } p \text { value) } \\
\text { (Total }=433)\end{array}$ \\
\hline \multirow{4}{*}{$\begin{array}{l}\text { Find useful as a } \\
\text { learning tool in } \\
\text { medical education }\end{array}$} & Textbooks & $265(96)$ & $152(96)$ & $p=0.92$ \\
\hline & Lecture Materials & $219(80)$ & $127(80)$ & $p=0.93$ \\
\hline & Subject Guidebooks & $210(76)$ & $131(83)$ & $p=0.09$ \\
\hline & SMP & $237(86)$ & $132(84)$ & $p=0.45$ \\
\hline \multirow{2}{*}{$\begin{array}{l}\text { Find SMP } \\
\text { Useful for }\end{array}$} & Social & $213(78)$ & $141(89)$ & $p=0.003^{*}$ \\
\hline & Educational & $251(91)$ & $132(84)$ & $p=0.01^{*}$ \\
\hline \multirow{5}{*}{$\begin{array}{l}\text { More often I have } \\
\text { used SMP for these } \\
\text { Educational } \\
\text { Purposes }\end{array}$} & Solving academic problems & $165(60)$ & $82(52)$ & $p=0.06$ \\
\hline & Research Work & $112(41)$ & $50(32)$ & $\mathrm{p}=0.01^{*}$ \\
\hline & Online group discussion & $79(29)$ & $61(39)$ & $p=0.29$ \\
\hline & Preparation for exam & $188(68)$ & $117(74)$ & $p=0.29$ \\
\hline & Seek help from teachers & $80(29)$ & $52(33)$ & $p=0.58$ \\
\hline \multirow{4}{*}{$\begin{array}{l}\text { Daily use of SMP } \\
\text { for social purposes }\end{array}$} & Facebook & $55(20)$ & $70(44)$ & $\mathrm{p}<0.001 *$ \\
\hline & WhatsApp & $260(95)$ & $141(89)$ & $p=0.04^{*}$ \\
\hline & YouTube & $221(80)$ & $135(85)$ & $p=0.21$ \\
\hline & Instagram & $181(66)$ & $128(81)$ & $\mathrm{p}<0.001^{*}$ \\
\hline \multirow{4}{*}{$\begin{array}{l}\text { Daily use of SMP } \\
\text { for Educational } \\
\text { purposes }\end{array}$} & Facebook & $39(14)$ & $42(27)$ & $\mathrm{p}<0.001 *$ \\
\hline & WhatsApp & $196(71)$ & $108(68)$ & $p=0.47$ \\
\hline & YouTube & $165(60)$ & $94(60)$ & $p=0.99$ \\
\hline & Instagram & $119(43)$ & $71(45)$ & $p=0.18$ \\
\hline \multirow{7}{*}{$\begin{array}{l}\text { I will find it useful if } \\
\text { institute featured } \\
\text { these on SMP }\end{array}$} & MCQs & $258(94)$ & $137(87)$ & $p=0.01 *$ \\
\hline & SAQs & $228(83)$ & $126(80)$ & $p=0.41$ \\
\hline & Pics \& Diagrams & $274(99)$ & $146(92)$ & $\mathrm{p}<0.01^{*}$ \\
\hline & Videos & $273(99)$ & $149(94)$ & $\mathrm{p}<0.01 *$ \\
\hline & Live Recordings & $199(72)$ & $105(67)$ & $p=0.13$ \\
\hline & Q \& A with teachers & $239(87)$ & $125(79)$ & $\mathrm{p}=0.03^{*}$ \\
\hline & Useful Links & $204(74)$ & $119(75)$ & $p=0.98$ \\
\hline \multirow{4}{*}{$\begin{array}{l}\text { I want SMP used at } \\
\text { the institute in } \\
\text { medical education }\end{array}$} & Definitely yes & $134(49)$ & $94(60)$ & \multirow{4}{*}{$p=0.08$} \\
\hline & Yes, after proper orientation & $124(45)$ & $51(32)$ & \\
\hline & Can join in peer group & $10(04)$ & $07(04)$ & \\
\hline & Don't want & $07(03)$ & $06(3.8)$ & \\
\hline \multirow{3}{*}{$\begin{array}{l}\text { Willingness for } \\
\text { Participation after } \\
\text { training }\end{array}$} & Active & $144(52)$ & $68(43)$ & \multirow{3}{*}{$p=0.04 *$} \\
\hline & Discuss & $44(16)$ & $25(16)$ & \\
\hline & Passive & $87(32)$ & $65(41)$ & \\
\hline
\end{tabular}

* Statistical significant difference.

sOnly survey finding of "useful" is presented in the table. 
Table 2 Year wise differences in medical students about SMP in medical education

\begin{tabular}{|c|c|c|c|c|c|}
\hline $\begin{array}{c}\text { Survey } \\
\text { Questions\$ }\end{array}$ & Options & $\begin{array}{l}\text { 1st year } \\
(n=125) \\
\text { No. }(\%)\end{array}$ & $\begin{array}{c}\text { 2nd year } \\
(n=151) \\
\text { No. (\%) }\end{array}$ & $\begin{array}{l}\text { 3rd year } \\
(n=157) \\
\text { No. }(\%)\end{array}$ & $\begin{array}{c}\text { Significance } \\
\text { ( } p \text { value) } \\
\text { (Total }=433 \text { ) }\end{array}$ \\
\hline \multirow{4}{*}{$\begin{array}{l}\text { Find useful as a } \\
\text { learning tool in } \\
\text { medical education }\end{array}$} & Textbooks & $123(98)$ & $142(94)$ & $152(97)$ & $p=0.15$ \\
\hline & Lecture Materials & $109(87)$ & $129(85)$ & $108(69)$ & $p<0.001 *$ \\
\hline & Subject Guidebooks & $100(80)$ & $119(79)$ & $122(78)$ & $p=0.93$ \\
\hline & SMP & 99 (79) & $125(83)$ & $145(92)$ & $p<0.01^{*}$ \\
\hline \multirow{2}{*}{$\begin{array}{l}\text { Find SMP } \\
\text { Useful for }\end{array}$} & Social & 99 (79) & $128(85)$ & $127(81)$ & $p=0.47$ \\
\hline & Educational & $111(89)$ & $127(84)$ & $145(92)$ & $p=0.07$ \\
\hline \multirow{5}{*}{$\begin{array}{l}\text { More often I have } \\
\text { used SMP for these } \\
\text { Educational } \\
\text { Purposes }\end{array}$} & Solving academic problems & $70(56)$ & $81(54)$ & $96(61)$ & $p=0.36$ \\
\hline & Research Work & $46(37)$ & $51(34)$ & $65(41)$ & $p=0.09$ \\
\hline & Online SGD & $39(31)$ & $45(30)$ & $56(36)$ & $p=0.06$ \\
\hline & Preparation for exam & $83(66)$ & $96(64)$ & $126(80)$ & $\mathrm{p}<0.01^{*}$ \\
\hline & Seek help from teachers & $49(39)$ & $37(25)$ & $46(29)$ & $p=0.03^{*}$ \\
\hline \multirow{4}{*}{$\begin{array}{l}\text { Daily use of SMP } \\
\text { for social purposes }\end{array}$} & Facebook & $26(21)$ & $45(30)$ & $54(34)$ & $p=0.11$ \\
\hline & WhatsApp & $116(93)$ & $135(89)$ & $150(96)$ & $p=0.11$ \\
\hline & YouTube & 99 (79) & $116(77)$ & $141(90)$ & $p<0.01^{*}$ \\
\hline & Instagram & $88(70)$ & $104(69)$ & $117(75)$ & $p=0.48$ \\
\hline \multirow{4}{*}{$\begin{array}{l}\text { Daily use of SMP } \\
\text { for Educational } \\
\text { purposes }\end{array}$} & Facebook & $16(13)$ & $30(20)$ & $35(22)$ & $p=0.02 *$ \\
\hline & WhatsApp & $96(77)$ & $95(63)$ & $113(72)$ & $p=0.03^{*}$ \\
\hline & YouTube & $78(62)$ & $82(54)$ & $99(63)$ & $p=0.13$ \\
\hline & Instagram & $47(38)$ & $61(40)$ & $82(52)$ & $p=0.04^{*}$ \\
\hline \multirow{7}{*}{$\begin{array}{l}\text { I will find it useful if } \\
\text { institute featured } \\
\text { these on SMP }\end{array}$} & MCQs & $115(92)$ & $137(91)$ & $143(91)$ & $p=0.94$ \\
\hline & SAQs & $112(90)$ & $113(75)$ & $129(82)$ & $p=0.01^{*}$ \\
\hline & Pics \& Diagrams & $124(99)$ & $143(95)$ & $153(98)$ & $p=0.09$ \\
\hline & Videos & $124(99)$ & $146(97)$ & $152(97)$ & $p=0.34$ \\
\hline & Live Recordings & $94(75)$ & $101(67)$ & 109 (69) & $p=0.60$ \\
\hline & Q \& A with teachers & $115(92)$ & $124(82)$ & $125(80)$ & $p=0.01^{*}$ \\
\hline & Useful Links & $102(82)$ & $101(67)$ & $120(76)$ & $p=0.03^{*}$ \\
\hline
\end{tabular}

* Statistical significant difference.

sOnly survey finding of "useful" is presented in the table.

\begin{tabular}{|c|l|c|c|c|c|}
\hline \multirow{4}{*}{$\begin{array}{c}\text { I want SMP used } \\
\text { at the institute }\end{array}$} & Definitely yes & $123(98)$ & $75(50)$ & $89(57)$ & \\
\cline { 2 - 6 } & Yes, after orientation & $109(87)$ & $62(41)$ & $57(36)$ & $\mathrm{p}=0.43$ \\
\cline { 2 - 6 } & Can join in peer group & $100(80)$ & $07(05)$ & $05(03)$ & \\
\cline { 2 - 6 } & Don't want & $99(79)$ & $07(05)$ & $06(04)$ & \\
\hline $\begin{array}{c}\text { Willingness for } \\
\text { Participation after } \\
\text { training }\end{array}$ & Active & $99(79)$ & $66(44)$ & $76(48)$ & \\
\cline { 2 - 6 } & Discuss & $111(89)$ & $23(15)$ & $27(17)$ & $54(34)$ \\
\cline { 2 - 6 }
\end{tabular}


Find SMP useful for social and educational purposes: $89 \%$ of boys find SMP useful for social purposes compared to $78 \%$ of girls, $p<0.01$ and $21 \%$ of female students had a neutral opinion about using SMP for social purposes compared to $9 \%$ of male students (not given in the table). This is reversed in the case of SMP being used for educational purposes where $91 \%$ of female students compared to $84 \%$ of male students find SMP useful for educational purposes, $p=0.016$ (Table 1 ). Almost $80 \%$ to
$85 \%$ of students of all semester find SMP useful for both social and educational purposes (Table 2).

Different Social Media Platforms used by the students: Everyone is using some type of SMP. Almost $60 \%$ to $66 \%$ of students use YouTube and WhatsApp for both social and educational purposes. Wikipedia (60.5\%) and Quora (39\%) are being used more for educational purposes. Facebook, Twitter, Instagram are mainly used for social purposes only (Not given in tables).

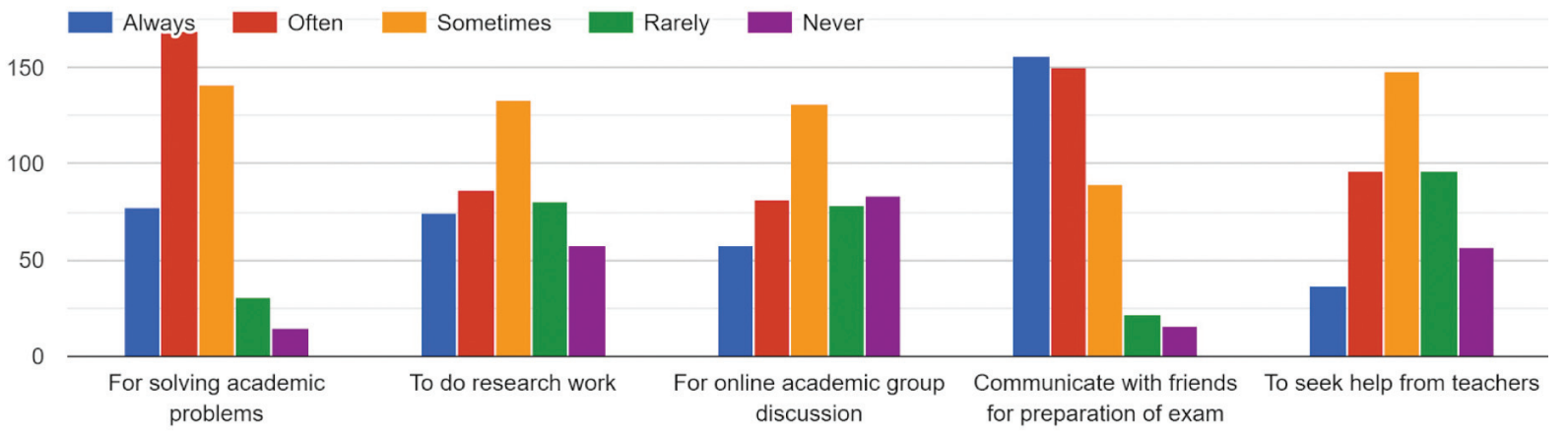

Frequency of SMP uses for educational purposes: For the question how they use SMP for educational purposes, majority of them (Always-156 and Often-150) use SMP to communicate with friends for the preparation of exam and more than $50 \%$ of students (Always-78 and Often-169) use for solving academic problems (figure 2). Female students $(40.7 \%$ ) are more often using SMP than male students (31.6\%) for research purpose, $p=0.006$. About $40 \%$ of first-year student use SMP more often to seek help from teachers than second $(24.5 \%)$ and third (29.3\%) year students, $\mathrm{p}=0.03$ and almost $80 \%$ of third-year students use SMP for preparation of exams more often than second (63\%) and first-year (66\%) students, $p=0.003$. There are no year-wise significant differences in the frequency of use of SMP for solving academic problems, research work, and SGD, p>0.05 (Table 2).

Daily use of SMP for social purposes: $97 \%$ of students use any of SMP at least once in a day. There are statistically significant differences for frequency of use of Facebook, WhatsApp and Instagram between male and female students for social purposes $(p<0.01)$ where male students use Facebook ( $44 \%$ vs $20 \%$ ) and Instagram ( $81 \%$ vs $65.8 \%$ ) for social purposes daily and female students use WhatsApp (95\% vs $89 \%$ ) daily, $p<0.01$. There is no statistically significant difference in daily use of YouTube (male $85 \%$ vs female $80 \%$ ). YouTube for social purposes is used daily by third-year students $(90 \%)$ compared to first $(79 \%)$ and second-year $(77 \%)$ students, $p=0.008$.

Daily use of SMP for educational purposes: Though the majority of students (73\%) don't use Facebook for educational purposes, $27 \%$ of male students do use it daily compared to only $14 \%$ of female students, $p<0.01$. Other SMPs like

WhatsApp, YouTube and Instagram had no significant difference in frequency of use between both sexes for educational purposes (Table 1). Third-year students are using WhatsApp, Facebook and Instagram for educational purposes daily more than first and the second-year, $p<0.05$. But no yearwise difference for YouTube use, $p=0.12$ (Table 2).

Usefulness of SMP features: Overall 90 to $95 \%$ say that they will find useful if pictures/diagrams, videos or video links, multiple-choice questions and even $Q$ \& $A$ with teachers are shared on their SMP by the institute. Female students find SMP more useful if MCQs ( $83 \%$ vs $80 \%$ ), Pictures \& Diagram (99.6\% vs $92 \%$ ), Videos (99\% vs $94 \%$ ) and Q \& A sessions ( $86 \%$ vs $79 \%$ ) are featured on their SMP by the institute, $p<0.01$. Nearly $70 \%, 75 \%$ and $80 \%$ of students of both sexes find live recordings, sharing of links and Short answer questions on their SMP by the institute more useful respectively, $p>0.05$ (Table 1). First-year students find short question answer, $Q$ \& A with teachers and sharing of links on their SMP more useful compared to second and third-year students, $\mathrm{p}<0.05$ while for other features like MCQs, Pictures, and Videos sharing, there is no year-wise statistically significant differences (Table 2)

Want to see SMP used at institute level in medical education: Almost 93\% want to see SMP used at institute level in medical education. Out of them, $40.6 \%$ say they will use SMP after proper orientation. Remaining $7 \%$ who are not ready or do not want SMP in medical education, $4 \%$ of them are ready to join in peer groups. Nearly $92 \%$ of both sexes and more than 95\% from all academic year want SMP to be used in medical education. 
Figure 3. Which activities will you participate after proper training to use SMP in medical education.

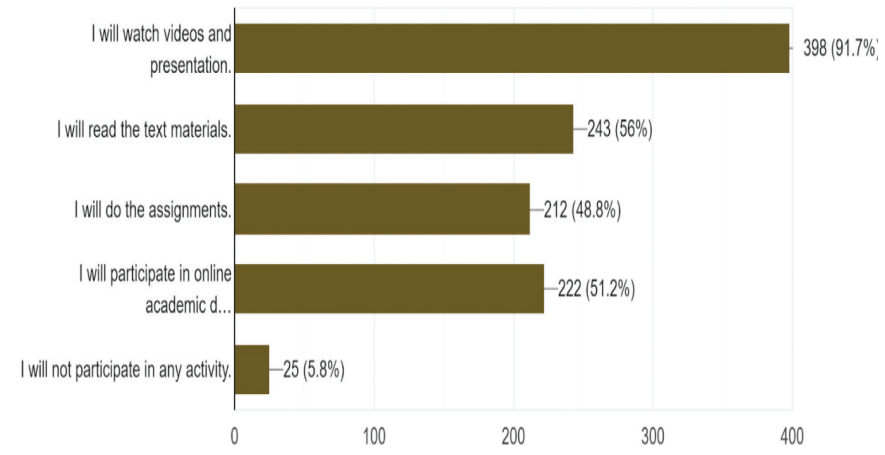

Willingness and levels of participation: When asked about which activity they would like to participate after proper training for using social media platforms in Medical Education, $92 \%$ said they would watch videos, presentations or live recordings. Almost $50 \%$ of students are ready for reading text materials online, academic group discussion and for completing assignments. 14 out of 25 students, as shown in the graph, have ticked some participation and also not participate in any activity (Graph 3).

When multiple options are combined to form three groups (Active, discussion, and passive participation) based on whether they are ready for doing the assignment. Those who will participate in reading, watching, and/or discussion along with ready to do the assignment (Active participation) are 212 (49\%) and those who are ready only for online discussion without assignment are 69 (15.9\%). Remaining 152 (35.1\%) are ready only for passive participation (watching or reading only) including those 11 (2.5\%) who will not participate in any activity.

Female students (52.4\%) are significantly more willing for active participation than male students (43\%), $p=0.04$ (Table 1). Firstyear students (56\%) are more ready for active participation followed by third (48.4\%) and second $(43.7 \%)$ year students, $\mathrm{p}=0.08$ (Table 2).

\section{Discussion:}

The present study focused on need assessment and willingness of first, second and third-year MBBS students of Prathima Institute of Medical Sciences, Karimnagar for using social media in medical education. All of them have smartphones and using social media routinely for personnel and academic purposes. In this survey almost 80 to $90 \%$ male and female students from all academic year consider SMP learning tool in medical education. This study's findings of undergraduate students' perception of using SMP for education purposes is similar to many studies like of Sandars and Schroter $\mathrm{J}^{(6)}$, White et al. ${ }^{(7)}$ of the USA, Adithya et al. ${ }^{(8)}$ of India that social media has positive impact on learning and professional development. In the study, S. Kaur and R. Manhas $^{(9)}$ noted that $83.3 \%$ of medical students of eight medical colleges of Punjab state use social media applications for educational purposes. In the survey by S. Lahiry et al. ${ }^{(10)}$, they described that $89 \%$ of undergraduate were using social media and mainly for academic purposes (82.73\%). S. Sorte et al. ${ }^{(11)}$ found that $81.25 \%$ of first-year students, who were taught using Facebook, ranked social media as an effective learning tool.

This study finds that SMP is a useful learning tool in medical education nearly equal to lecture materials and subject notes and Sattar K et al. ${ }^{(12)}$ had found that $80 \%$ of students considered SMP useful for lectures and subject notes. Facebook is mainly used for social purposes in this study similar to literature review findings of Pande T et al. ${ }^{(13)}$. Almost two-third students in this study use YouTube, Wikipedia and WhatsApp for educational purposes similar to the systematic review findings of M. Sterling et al. ${ }^{(14)}$ where these SMPs are more commonly used to teach technical skills.

One-third students use SMP for sharing medical information and for preparation of exam in this study similar to Sattar K et al. ${ }^{(12)}$ study where $96 \%$ of students used SMP for same purposes with no differences between male and female.

Although around 50 to $60 \%$ of students with no gender or year wise difference are using SMP for solving academic problems and online group discussion which require quick feedback. In Hall et al. ${ }^{(15)}$ study, $75 \%$ agreed that they frequently used social media for discussing academic problems and Adithya et al ${ }^{(8)}$ found that social media is most frequently used for information and getting in touch with friends. The study conducted by Sen $S$ et al. ${ }^{(16)}$ showed that $78 \%$ students discuss cases on networking apps (Facebook/WhatsApp).

In this study, third-year students are using social media for educational purposes daily more than first and the second-year, $p<0.05$ which is same as of R Andrea et al. ${ }^{(17)}$ where third-year students usually access their devices more than 24 hours per week. Vishal $\mathrm{M}$ et al. ${ }^{(18)}$ study found that $97 \%$ of the students have been using Facebook and WhatsApp daily contrary to the present study where $20 \%$ using Facebook and $70 \%$ using WhatsApp daily for educational purposes. S. Lahiry et al. ${ }^{(10)}$ noted that WhatsApp $(90.6 \%)$, Facebook (83\%) were the most popular platforms, with daily (91.82\%) usage clearly more frequent than weekend-only usage (6.29\%). These findings are considerably similar to this study participants' responses of more often use of SMP daily.

\section{Conclusion:}

Use of SMP for social and educational purposes go hand in hand. Although the pattern and choice of SMP are different between social and educational purposes. There is no big difference in gender as well as year wise in SMP uses. Most 
students are willing to include SMP in medical education as a learning tool and ready to participate in different activities if they get the required training. As all students have smartphones and efficiently utilizing different services on their devices, SMP can become an effective learning tool for studentcentred model incorporating their active participation in the learning process which include integrated, inquiry-based, cooperative learning along with greater flexibility in learning and teaching methods.

Limitation: Faculties view and their training for using social media need to be assessed. Integrity and privacy are two major concerns regarding the use of social media but we have not asked about these issues in this survey.

\section{REFERENCES}

1. Arnbjörnsson E. The Use of Social Media in Medical Education: A Literature Review. Creat Educ. 2014;05(24):2057-61.

2. Pei $\mathrm{L}, \mathrm{Wu} \mathrm{H}$. Does online learning work better than offline learning in undergraduate medical education? A systematic review and meta-analysis. Med Educ Online [Internet]. 2019 Jan 1;24(1):1666538. Available from: 10.1080/10872981.2019.1666538

3. Flynn L V., Jalali A, Moreau KA. Learning theory and its application to the use of social media in medical education. Postgrad Med J [Internet]. 2015 Oct ;91(1080):556-60. Available from: http://pmj.bmj.com/ lookup/doi/10.1136/postgradmedj-2015-133358

4. Tang B, Coret A, Barron H, Qureshi A, Law M. Online lectures in undergraduate medical education: how can we do better? Can Med Educ J [Internet]. 2019;10(1):e137-9. Available from: http:// www.ncbi.nlm.nih.gov/pubmed/30949271

5. Milic NM, Trajkovic GZ, Bukumiric ZM, Cirkovic A, Nikolic IM, Milin JS, et al. Improving education in medical statistics: Implementing a blended learning model in the existing curriculum. García O, editor. PLoS One [Internet]. 2016 Feb 9 [cited 2019 Oct 5];11(2):e0148882. Available from: https://dx.plos.org/10.1371/journal.pone.0148882

6. Sandars J, Schroter S. Web 2.0 technologies for undergraduate and postgraduate medical education: An online survey. Postgrad Med J. 2007;83(986):759-62.

7. White J, Kirwan P, Lai K, Walton J, Ross S. "Have you seen what is on Facebook?" the use of social networking software by healthcare professions students. BMJ Open. 2013;3(7):1-8.

8. Adithya Kumari, H. Ali, K. S., \& Mahadevamurthy M. Use of Social Media among Dental Students of Farooqia Dental College, Mysore: A Study. Int Conf Open Access-Scholarly Commun Reincarnated A Futur Approach. 2013;19-20.
9. Kaur S, Manhas R. Use of Social Media among Medical Teachers and Students of Punjab, India?: A Study. Asian J Inf Sci Technol. 2018;8(3):1-9.

10. Lahiry S, Choudhury S, Chatterjee S, Hazra A. Impact of social media on academic performance and interpersonal relation: A cross-sectional study among students at a tertiary medical center in East India. J Educ Health Promot [Internet]. 2019 [cited 2020 Jan 4];8:73. Available from: http://www.ncbi.nlm.nih.gov/pubmed/31143790

11. Sorte SR, Rathod SB. Social networking sites as informal learning tool. Indian J Physiol Pharmacol. 2016;60(4):4036.

12. Sattar K, Ahmad T, Abdulghani HM, Khan S, John J, Meo SA. Social networking in medical schools: Medical student's viewpoint. Biomed Res. 2016;27(4):1378-84.

13. Pander T, Pinilla $S$, Dimitriadis K, MR F. The Use of Facebook in Medical Education - A Literature Review. GMS Z Med Ausbild. 2014;3(31):1-9.

14. Sterling $M$, Leung $P$, Wright $D$, Bishop TF. The use of social media in graduate medical education: A systematic review [Internet]. Vol. 92, Academic Medicine. 2017 [cited 2019 Nov 2]. p. 1043-56. Available from: http:// insights.ovid.com/crossref?an=00001888-20170700000052

15. Hall M, Hanna LA, Huey G. Use and views on social networking sites of pharmacy students in the United Kingdom. Am J Pharm Educ. 2013;77(1).

16. Sen S, Sarode S, Ilahi A, Sarode S, Deolia S, Sen R. Assessing the of Role of Social Media in Dental Education. Int J Oral Heal Med Res. 2016;3(3):10-5.

17. Andrea RR, Gerardo ET, Darío M-EJ, Enrique R-MM. Information and communication technology, mobile devices, and medical education. bioRxiv [Internet]. 2018 Sep 18 [cited 2019 Sep 24];420281. Available from: https:/ /www.biorxiv.org/content/10.1101/420281v1

18. Vishal M, Kriti G, Gauri M, Shiv Kumar S. Influence Of Social Networking Sites ( Snss ) On Dental Students?: A CrossSectional Study. Univ J Dent Scie. 2018;4(1):43-7.

How to cite this article : Kashif S M,Baig Mirza. The usage pattern and willingness of undergraduate medical students for including social media platforms as learning tool in medical education- an online survey. Perspectives in Medical Research 2020; 8(1):11-17

Sources of Support: Nil, Conflict of interest: None declared 